Article

\title{
The foraging Gene Is Involved in the Presence of Wings and Explorative Behaviours in Parthenogenetic Females of the Aphid Myzus persicae
}

\author{
Mauro Mandrioli ${ }^{1, *(D)}$ and Gian Carlo Manicardi ${ }^{2}$ \\ 1 Department of Life Sciences, University of Modena and Reggio Emilia, Biology Building, Via Campi 213/D, \\ 41125 Modena, Italy \\ 2 Department of Life Sciences, University of Modena and Reggio Emilia, Padiglione Besta, Via Amendola 2, \\ 41122 Reggio Emilia, Italy; manigi04@unimore.it \\ * Correspondence: mauro.mandrioli@unimore.it
}

check for updates

Citation: Mandrioli, M.; Manicardi, G.C. The foraging Gene Is Involved in the Presence of Wings and Explorative Behaviours in Parthenogenetic Females of the Aphid Myzus persicae. Life 2022, 12, 369. https://doi.org/10.3390/ life12030369

Academic Editors: Federica Talarico, Anita Giglio and Dmitry L. Musolin

Received: 29 January 2022

Accepted: 2 March 2022

Published: 3 March 2022

Publisher's Note: MDPI stays neutral with regard to jurisdictional claims in published maps and institutional affiliations.

Copyright: (c) 2022 by the authors. Licensee MDPI, Basel, Switzerland. This article is an open access article distributed under the terms and conditions of the Creative Commons Attribution (CC BY) license (https:// creativecommons.org/licenses/by/ $4.0 /)$.

\begin{abstract}
The foraging gene (for) encodes for a cyclic guanosine monophosphate (cGMP)-dependent protein kinase involved in behavioural plasticity in aphids and in other insects. In this paper, we analysed the complete for sequence in eight clones of the peach potato aphid Myzus persicae, reporting the presence of nonsense and frameshift mutations in three studied clones characterized by a reduced number of winged females and by the absence of exploratory behaviours. Quantitative PCR experiments evidenced similar results in clones possessing for genes with a conserved coding sequence, but low expression levels. The comparison of the for transcriptional level in Myzus persicae persicae and Myzus persicae nicotianae showed very different expression in the two studied M. $p$. nicotianae clones so that our data did not support a previous hypothesis suggesting that a differential for expression was related to ecological specialization of M. p. nicotianae. In view of its role in both the dispersal of winged females and exploratory behaviours, the screening of the for sequences could be useful for predicting invasions of cultivated areas by peach potato aphids.
\end{abstract}

Keywords: foraging; behavioural plasticity; winged aphids; peach potato aphid

\section{Introduction}

In the last decades, several well-studied examples that shed light on genes and pathways underlying insect behavioural plasticity have been described [1-5]. In particular, single genes that affect the regulation of complex, yet distinct, behaviour patterns have been identified, suggesting that mutations altering their expression may vary the response to specific environmental stimuli generating behavioural plasticity [1,3-6].

Several recent achievements in this research field have been related to the foraging gene (for), which encodes a cyclic guanosine monophosphate (cGMP)-dependent protein kinase (PKG), suggesting that it may regulate different behaviours in several insects, including Diptera, Hymenoptera, Coleoptera and Hemiptera [1,3,5-10].

Originally identified as a behaviourally polymorphic gene that drives alternative foraging strategies in the fruit fly Drosophila melanogaster [11], the for gene has been successively deeply studied in social insects, where it has been observed that its differential expression plays a key role in the division of labour in diverse castes $[5,6,12]$. In particular, for regulates worker transitions between behavioural tasks and specific behavioural traits associated with morphological castes [5].

Although the specific neurological role of for in the insect brain is currently unknown, studies in some insect species indicated that PKG signalling plays a conserved role in the neuronal plasticity of sensory, cognitive and motor functions, which underlie behaviours related to appetitive learning, aggression, stress response, phototaxis and response to pheromones [5]. 
A for gene orthologue has also been identified in the pea aphid Acyrthosiphon pisum (Apfor) [13,14], where it is highly expressed in adults reared under crowded conditions. In particular, it has been suggested that Apfor may trigger the shift from sedentary to exploratory behaviour [13].

A for orthologue has also been studied in the peach potato aphid Myzus persicae (Mpfor) comparing generalist biotypes with tobacco-specialized races (generally identified as Myzus persicae nicotianae), suggesting that Mpfor influences the process of host searching and the evolution of ecological specialization [14]. At the same time, it has been suggested that low levels of for expression are related to a reduced PKG expression, resulting in reduced mobility, foraging activity and dispersal [14].

Interestingly, Tapia and colleagues [14] suggested that the low for expression observed in $M . p$. nicotianae could reinforce differences in diet breadth and ecological specialization by, for instance, reducing resource-searching behaviours and mobility. This hypothesis has been supported by the presence of a higher for transcription in alates that are responsible for host searching and dispersal in generalist clones in respect to specialized ones [14].

Considering that the dispersal of winged females is a key element to determine invasiveness of aphids, here, we compared the for sequence in eight $M$. persicae clones in order to evaluate if the screening of the for sequence could be useful to predict invasions of cultivated areas by peach potato aphids. Lastly, we compared the for expression in M. $p$. persicae and M. p. nicotianae to confirm the role of Mpfor in promoting ecological specialization.

\section{Materials and Methods}

\subsection{Sampling and Rearing}

Specimens of $M$. persicae were obtained from eight aphid lineages maintained as a colony of parthenogenetic females on pea Pisum sativum (cv 'Meraviglia d'Italia') plants at $19{ }^{\circ} \mathrm{C}$ with a light-dark regime of $16 \mathrm{~h}$ light and $8 \mathrm{~h}$ darkness that ensures parthenogenic reproduction (virginiparous females). Aphids were transferred to fresh pea plants once a week.

Aphids were reared in parallel at low and high population densities. In particular, five wingless parthenogenic females were transferred in an insect box and their progenies collected after a week. This low population density condition provided good food quality and a large space for female reproduction. High population density was obtained by transferring thirty females in a box containing a single pea plant and left there, giving rise to several generations until, after a week, crowded conditions were achieved.

Aphid clones were collected from three countries: $M$. persicae clone $1 \mathrm{GK}$ was collected from Greece and kindly supplied by John Margaritopoulos (Greece); clones K1, K10, D type and 229 were collected from Scotland and were kindly supplied by Brian Fenton (Scotland); clones 1ITA, 33H and 7 were collected from Italy and were kindly supplied by Emanuele Mazzoni (Italy). Clones 1GK and K1 were previously identified as M. p. nicotianae using microsatellite-based and chromosomal analyses $[15,16]$. A detailed description of each clone is reported in Table 1.

Isofemale clonal lineages were obtained from lines of aphids issuing from a single female and maintained in culture in the laboratory on pea plants in order to obtain homogeneous aphid samples. Clonal lines are periodically checked with different biochemical, molecular and biological assays in order to ensure the stability of the biological traits (chromosomal number, resistance type and level, reproductive modalities, etc.) observed at their first identification. 
Table 1. Description of the main biological traits of the eight studied M. persicae clones. The column "Description" presents a general description of each clone and also distinguishes clones with generalist feeding traits as opposed to those specialized for tobacco, identified as M. $p$. nicotianae. The insecticide resistance is reported in term of resistance levels, with $S$ being sensitive and R3 being the most resistant. Esterase confers resistance to insecticides such as organophosphates. Knockdown (kdr) and super knockdown (skdr) are involved in resistance to pyrethroids.

\begin{tabular}{|c|c|c|c|c|c|}
\hline Clone & $\begin{array}{c}\text { Year first } \\
\text { Identification }\end{array}$ & Host & Description & Insecticide Resistance & Reproductive Mode \\
\hline 1ITA & 2003 & peach & $\begin{array}{l}\text { susceptible to insecticides, } \\
\text { generalist, common }\end{array}$ & S & holocyclic \\
\hline K1 & 2004 & potato & $\begin{array}{l}\text { long-term resistant, identified } \\
\text { as M.p. nicotianae, common }\end{array}$ & $\begin{array}{l}\text { R3 resistance due to esterase } \\
\text { gene duplication, kdr mutation }\end{array}$ & holocyclic \\
\hline K10 & 2004 & potato & $\begin{array}{l}\text { long-term resistant, } \\
\text { generalist, common }\end{array}$ & $\begin{array}{l}\mathrm{R} 3 \text { resistance due to esterase } \\
\text { gene duplication, kdr mutation }\end{array}$ & $\begin{array}{l}\text { obligate } \\
\text { parthenogenetic }\end{array}$ \\
\hline 1GK & 2002 & $\begin{array}{l}\text { shepherd's } \\
\text { purse }\end{array}$ & $\begin{array}{l}\text { susceptible, identified as } \\
\text { M. p. nicotianae, common }\end{array}$ & $\mathrm{S}$ & holocyclic \\
\hline 229 & 2004 & potato & $\begin{array}{l}\text { long-term resistant, } \\
\text { generalist, common }\end{array}$ & $\begin{array}{l}\mathrm{R} 3 \text { resistance due to esterase } \\
\text { gene duplication }\end{array}$ & holocyclic \\
\hline $33 \mathrm{H}$ & 2012 & potato & $\begin{array}{l}\text { susceptible to insecticides, } \\
\text { generalist, common }\end{array}$ & $\mathrm{S}$ & $\begin{array}{l}\text { obligate } \\
\text { parthenogenetic }\end{array}$ \\
\hline 7 & 2008 & peach & $\begin{array}{l}\text { susceptible to insecticides, } \\
\text { generalist, common }\end{array}$ & 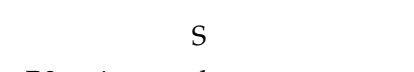 & $\begin{array}{l}\text { obligate } \\
\text { parthenogenetic }\end{array}$ \\
\hline D type & 2001 & potato & $\begin{array}{l}\text { long-term resistant, } \\
\text { generalist, common }\end{array}$ & $\begin{array}{l}\text { R3 resistance due to esterase } \\
\text { gene duplication, kdr mutation, } \\
\text { skdr mutation }\end{array}$ & $\begin{array}{l}\text { obligate } \\
\text { parthenogenetic }\end{array}$ \\
\hline
\end{tabular}

Aphids reared in high population densities have also been used to evaluate the presence of winged adults and wingless foragers. In particular, the number of both winged adults and unwinged walking aphids exploring the insect box was evaluated after a week of breeding in crowded conditions. This approach evidenced an abundant presence of both alate females and walking foragers in response to crowding clones 1ITA, 1 GK, K10, D-type and 229, whereas clones $33 \mathrm{H}, \mathrm{K} 1$ and 7 consisted of unwinged females only, even if maintained on crowded pea plants.

\subsection{RNA Extraction and foraging Gene Amplification}

RNA extraction was performed with the SV Total RNA Isolation System (Promega), according to the supplier's suggestions. RNA samples were quantified by spectrophotometric absorbance measurements using a NanoDrop ${ }^{\mathrm{TM}}$ ND1000 Spectrophotometer (Thermo Fisher Scientific, Waltham, MA, USA).

Amplification of an internal $807 \mathrm{bp}$-long portion of the for gene was performed by RT-PCR with the Access RT-PCR System (Promega) and the primers F-for (5'-GAGACGTTC TACAATGCTGGA) and R-for (5'-AGCAAAACCAAAGTCGACCA) at an annealing temperature of $57^{\circ} \mathrm{C}$ for $1 \mathrm{~min}$ using $0.5 \mu \mathrm{g}$ of polyA+ mRNA. Primers were designed using the webtool Primer3 (freely available at the address https:/ / primer3.ut.ee/, last access 28 January 2022) using the template sequence JF776573.1, annotated as for orthologue in the pea aphid A. pisum. RACE amplification was carried out to complete the for sequence using the $5^{\prime} / 3^{\prime}$ RACE Kit (Roche), according to the supplier's instructions.

Amplified fragments were cloned with the TA Cloning ${ }^{\circledR}$ kit (Invitrogen) and transformed into electrocompetent One shot ${ }^{\circledR}$ TOP10 Escherichia coli cells (Invitrogen). Recombinant plasmids from ten positive colonies for each aphid clone were extracted, purified and sequenced at BMR Genomics (Padua, Italy).

Sequence alignments were performed using the software Biogen ${ }^{\circledR} C L C$ sequence viewer (Aarhus, Denmark) and with the nBLAST and pBLAST tools available at NCBI (http:/ / blast.ncbi.nlm.nih.gov/Blast.cgi, last access 28 January 2022). The analysis of the conserved domains in the coded foraging proteins was carried out using the Conserved Domain Search tool available at NCBI (https:/ / www.ncbi.nlm.nih.gov/Structure/cdd/wrpsb.cgi, last access 28 January 2022). 


\section{3. qPCR Experiments and Statistical Analysis}

The comparison of the expression level of the for genes in the eight M. persicae clones was accomplished via quantitative real-time PCR experiments (qPCR). In particular, RNA samples for qPCR were extracted from a pool of ten M. persicae wingless parthenogenic adults collected after a week of breeding in crowded conditions using the Quick-RNA ${ }^{\mathrm{TM}}$ Miniprep Kit (Zymo Research, Freiburg, Germany) following the manufacturer's protocol. All RNA samples were double-checked for purity and quantified using both Qubit ${ }^{\circledR}$ RNA HS Assays (Invitrogen, Carlsbad, CA, USA) and NanoDrop ${ }^{\mathrm{TM}}$ ND1000 Spectrophotometer (Thermo Fisher Scientific, Waltham, MA, USA).

The mRNA was reverse-transcribed to cDNA using the iScript ${ }^{\circledR} c D N A$ Synthesis Kit (Bio-Rad Laboratories, Inc., Hercules, CA, USA) according to the manufacturer's instructions. The qPCR reaction was performed using a SsoAdvanced ${ }^{\mathrm{TM}}$ Universal $S Y B R^{\circledR}$ Green Supermix (Bio-Rad Laboratories, Inc., Hercules, CA, USA) with the specifically designed primers F-for_qPCR (5'-TGGAGTCTTGTCTTGGTGGT) and R-for_qPCR (5'ATGCTTCAAGACACATCCG), following instructions provided by the manufacturer and using $1 \mu \mathrm{g}$ of polyA+ mRNAs.

The applied thermal profile was as follows: $95{ }^{\circ} \mathrm{C}$ for $10 \mathrm{~min}(1 \mathrm{cycle}), 95{ }^{\circ} \mathrm{C}$ for $2 \mathrm{~min}$, and $58^{\circ} \mathrm{C}$ for $30 \mathrm{~s}$ (30 cycles). All the reactions were performed in triplicate on a CFX96 Touch Real-time PCR detection system (Bio-Rad Laboratories, Inc., Hercules, CA, USA). Once the amplification reaction was completed, the melting curves were inspected for all the amplicons. Relative quantification of qPCR data was obtained through the $2^{-(\Delta \Delta C t)}$ method, according to Livak and Schmittgen [17]. Statistical analyses were performed with SPSS Statistics 25 (IBM Corp, released 2017, Armonk, NY, USA). One-way analysis of variance (ANOVA) was applied (Levene test, $p<0.05$ ).

\section{Results and Discussion}

The combined use of RT-PCR and RACE allowed the amplification of the complete for gene in the eight studied M. persicae clones, showing the presence of a $2310 \mathrm{bp}$ long coding sequence for all M. persicae clones. The length of the Mpfor coding sequence is in agreement with data reported in the pea aphid A. pisum, where two orthologues have been identified with respective sizes of $2331 \mathrm{bp}$ for Apfor 1 and $2112 \mathrm{bp}$ for Apfor 2 [13].

As reported by Tares et al. [13], the Apfor orthologues differ in the first two exons, whereas they perfectly overlap in their following sequence. In particular, exons 1 and 2 of Apfor 2 are located within the intron 2 of the Apfor 1 gene suggesting that these exons are spliced in the Apfor 1 variant. The presence of a single for gene in $M$. persicae supports the occurrence of a specific duplication in the A. pisum lineage.

The M. persicae coded foraging protein showed a $99 \%$ and $96 \%$ identity with the A. pisum Apfor2 and the D. melanogaster foraging respectively, whereas a lower identity $(86.7 \%)$ was obtained for the Apfor1 protein, suggesting that this probably represents a paralogous copy of the for gene.

Nucleic sequence alignment evidenced a very high sequence conservation in the $M$. persicae clones 1ITA, 1GK, 229, K10 and D-type, with sequence identity ranging from 99.69 to $100 \%$ (Table 2). Interestingly, despite the high conservation of their DNA sequence in terms of whole sequence identity, clones $33 \mathrm{H}, \mathrm{K} 1$ and 7 possessed severe mutations affecting the conservation of the coded foraging peptide (Figures 1-3). In particular, frameshift mutations were present in clones $33 \mathrm{H}$ (Figure 1) and K1 (Figure 2), whereas nonsense mutations were observed in clone 7 (Figure 3). 
Table 2. Summary of results of the for nucleic sequence alignment in the studied M. persicae clones.

\begin{tabular}{|c|c|c|c|c|c|c|c|c|}
\hline 1ITA & $100 \%$ & & & & & & & \\
\hline 1GK & $99.91 \%$ & $100 \%$ & & & & & & \\
\hline 229 & $100 \%$ & $99.91 \%$ & $100 \%$ & & & & & \\
\hline K1 & $99.82 \%$ & $99.74 \%$ & $99.82 \%$ & $100 \%$ & & & & \\
\hline D type & $100 \%$ & $99.91 \%$ & $100 \%$ & $99.82 \%$ & $100 \%$ & & & \\
\hline K10 & $99.74 \%$ & $99.65 \%$ & $99.74 \%$ & $99.56 \%$ & $99.74 \%$ & $100 \%$ & & \\
\hline $33 \mathrm{H}$ & $99.87 \%$ & $99.78 \%$ & $99.87 \%$ & $99.69 \%$ & $99.87 \%$ & $99.61 \%$ & $100 \%$ & \\
\hline \multirow[t]{2}{*}{7} & $99.87 \%$ & $99.78 \%$ & $99.87 \%$ & $99.69 \%$ & $99.87 \%$ & $99.61 \%$ & $99.74 \%$ & $100 \%$ \\
\hline & 1ITA & 1GK & 229 & K1 & D type & K10 & $33 \mathrm{H}$ & 7 \\
\hline
\end{tabular}
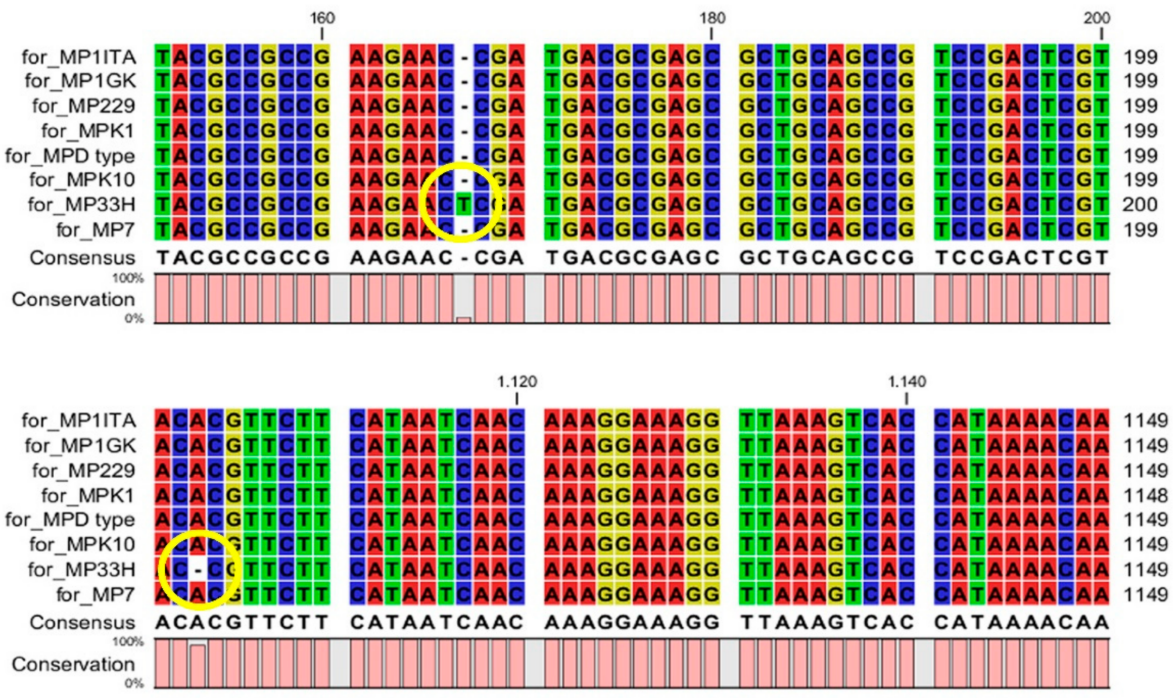

Figure 1. Nucleic sequence alignment appeared in the $M$. persicae clone $33 \mathrm{H}$ two frameshift mutations (shown by the yellow circles) occurring, respectively, in portion 150-200 and 1100-1149 of the Mpfor gene.

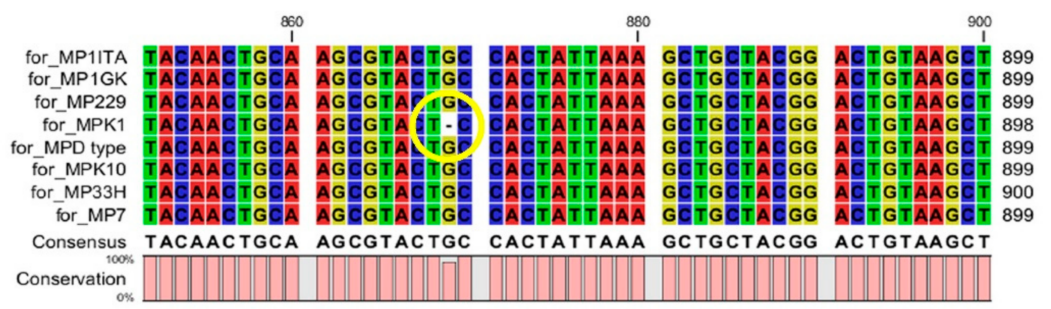

1.920

1.940

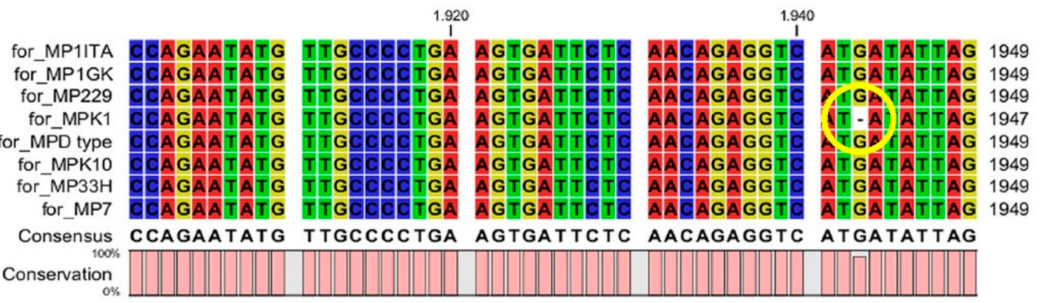

Figure 2. Nucleic sequence alignment evidenced in the M. persicae clone K1 two frameshift mutations (shown by the yellow circles) occurring, respectively, in portion 850-899 and 1900-1949 of the Mpfor gene. 


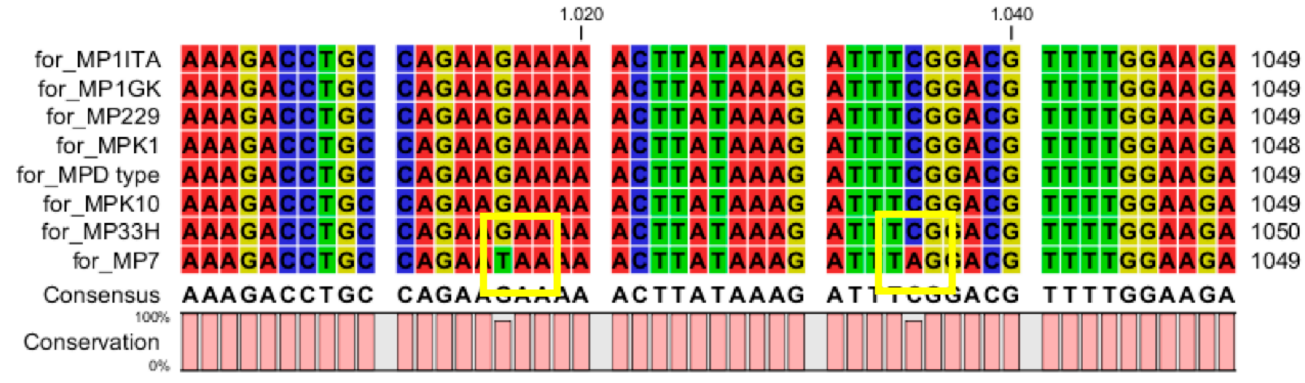

Figure 3. Nucleic sequence alignment evidenced in the M. persicae clone 7 two nonsense mutations (shown by the yellow squares) occurring in the portion 1000-1049 of the Mpfor gene. In particular, in the first mutation the GAA codon-coding for serine is changed into the TAA codon corresponding to a stop codon. Similarly, in the second mutation the TCG codon coding for glutamic acid is changed into the TAG codon corresponding to a stop codon.

The analysis of the foraging coded peptide evidenced the presence of missense mutations in clones 1GK (Figure 4) and K10 (Figure 5), but they did not change the structure of both functional domains and active sites suggesting that these mutations did not alter the functionality of the coded protein.

A

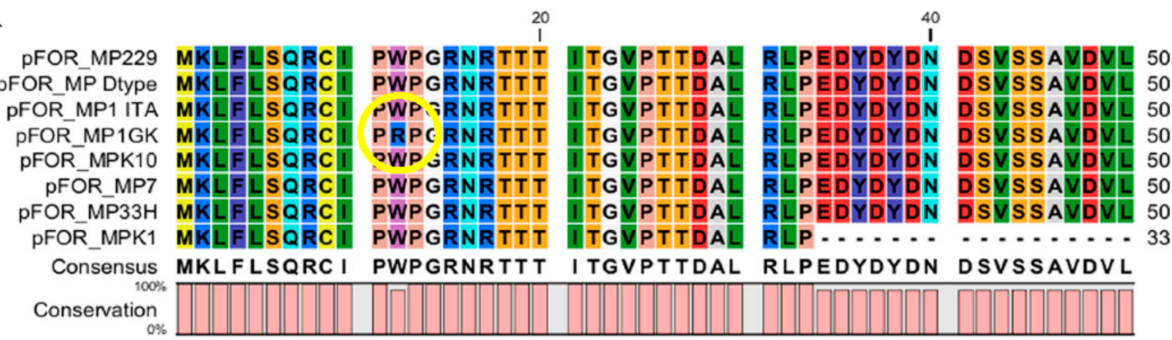

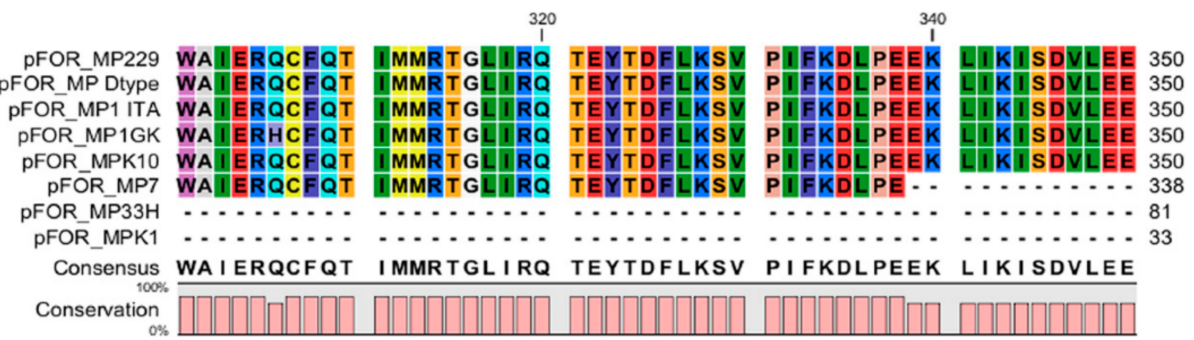

B

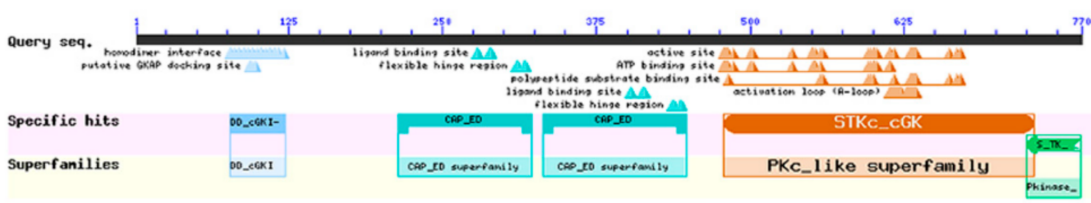

Figure 4. Protein sequence alignment evidenced in the $M$. persicae clone $1 G K$ a missense mutation (A) (shown by the yellow circle), but the coded protein possessed both the conserved domains and active sites typically present in functional foraging proteins (B). Conserved domains are visualized in the line labelled "Specific Hits", whereas "Superfamilies" represent the cluster of evolutionary conserved domains identified in the coded foraging proteins (labelled as "Query Seq"). 
A
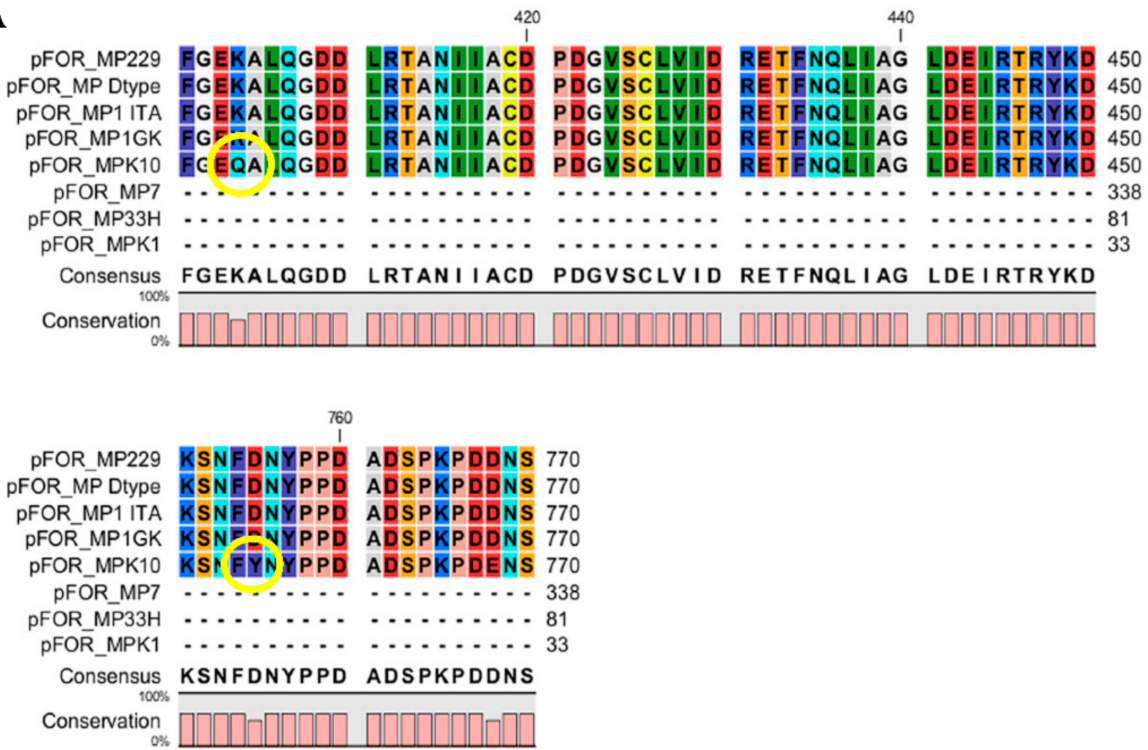

B

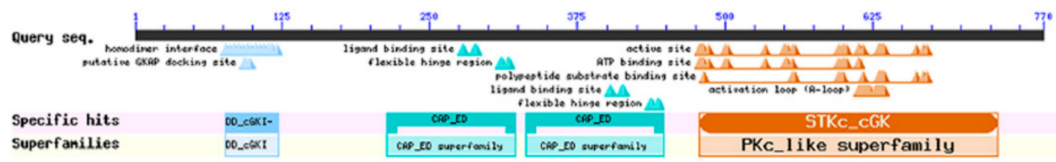

Figure 5. Protein sequence alignment evidenced in the M. persicae clone K10 two missense mutations (A) (shown by the yellow circles), but the coded protein possessed both conserved domains and actives sites typically present in functional foraging proteins (B). Conserved domains are visualized in the line labelled "Specific Hits", whereas "Superfamilies" represent the cluster of evolutionary conserved domains identified in the coded foraging proteins (labelled as "Query Seq").

The analysis of the qPCR experiments (Figure 6) evidenced different expression levels of the for gene in the studied $M$. persicae clones. In particular, they can be subdivided into three different groups with high, medium and low for expression. Clones with severe mutations (33H, K1 and 7) all showed low for expression levels.

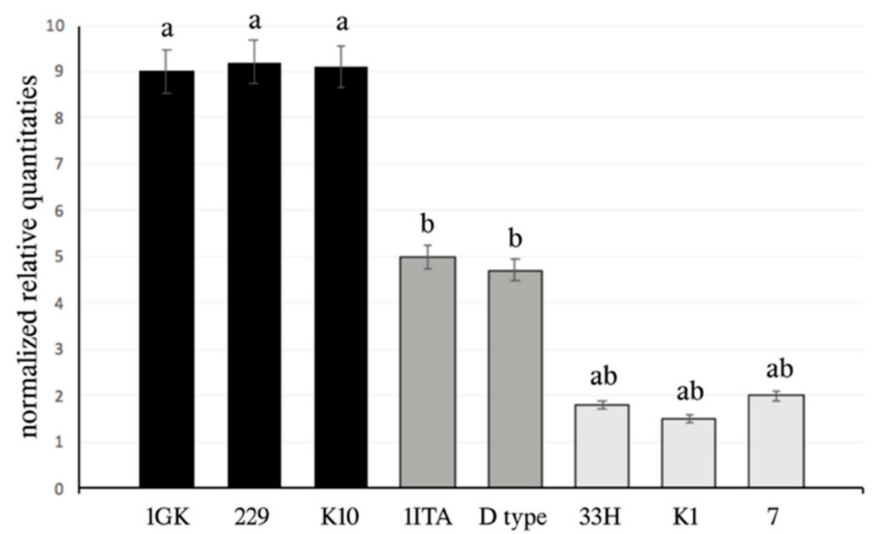

Figure 6. Normalized relative quantitative expression of for genes coding evidence high for expression level in clones 1GK, 229 and K10, whereas expression was scarce in the other clones and very low in clones $33 \mathrm{H}, \mathrm{K} 1$ and 7 , possessing severe mutations in the coding sequence. Bars indicate standard errors. 
The higher for expression was observed in clones 1GK, 229 and K10, whose wingless adults and nymphs moved greater distances on crowded plants (exploratory behaviour) in respect to the other clones (Table 2).

These results are in agreement with data obtained in D. melanogaster, where the rover allele was isolated in larvae that traverse a large area while feeding [11]. Similar results have also been reported in $A$. pisum, where different behavioural variants have been observed in adults under crowded conditions, in addition to the typical production of winged morphs able to disperse over a long distance (Table 3). The behavioural differences observed in A. pisum have been related to the higher for expression in more mobile aphids [13]. As a consequence, the high for expression level observed in clones 1GK, 229 and K10 can be associated with the presence of exploratory behaviours due to crowded conditions.

Table 3. Summary of the results observed in each M. persicae clone for the presence/absence of for mutations, alate females and exploratory behaviour.

\begin{tabular}{|c|c|c|c|}
\hline Clone & $\begin{array}{c}\text { Presence (+) or } \\
\text { Absence (-) of } \\
\text { Severe Mutations }\end{array}$ & $\begin{array}{c}\text { Abundance }(+) \text { or } \\
\text { Absence }(-) \text { of } \\
\text { Alate Females }\end{array}$ & $\begin{array}{c}\text { Presence }(+) \text { or } \\
\text { Absence }(-) \text { of } \\
\text { Explorative Behavior }\end{array}$ \\
\hline 1ITA & - & + & - \\
\hline $1 \mathrm{GK}$ & - & ++ & + \\
\hline 229 & - & ++ & + \\
\hline $33 \mathrm{H}$ & + & - & - \\
\hline K10 & - & ++ & + \\
\hline K1 & + & - & - \\
\hline 7 & + & - & - \\
\hline D type & - & + & - \\
\hline
\end{tabular}

Tares et al. [13] showed that Apfor is highly expressed in nymphs resulting in alate females, so they proposed an involvement of this gene in wing formation and in the flight capacity of the pea aphid. Similarly, clones 1GK, 229 and K10 simultaneously showed the greatest abundance of winged individuals and the highest for expression, suggesting the role of this gene in wing formation in the studied $M$. persicae clones. Moreover, the simultaneous presence of severe mutations and very low for expression was observed in clones $33 \mathrm{H}, \mathrm{K} 1$ and 7 that lacked winged females on crowded plants, further supporting the role of the for gene in wing formation in $M$. persicae.

Similar results were observed in the honeybee Apis mellifera, where high for expression levels were related to the transition from nurses to foragers outside the hive [18,19], and in different ant species, where peaks in the for expression were observed in foragers [20-22]. These data, together with an extensive array of further studies describing for role [23], clearly support the suggestion that the foraging gene is an evolutionary conserved modifier of behaviour in insects.

Our data, as a whole, suggest that for alleles could allow for a differential adaptation of the M. persicae clones to unfavourable environmental conditions, such as overcrowding. In particular, the presence of short-term adaptive responses based on the presence of winged females and exploratory behaviours could confer a remarkable invasive potential to peach potato aphids, making them efficient pests.

Interestingly, some odours and pheromones enhance the expression of the for orthologue in nematodes [24]. This regulatory effect could also be an interesting further research topic in $M$. persicae, since alarm pheromone mediates the production of winged dispersal morphs in several aphid species [25]. The ability of alarm pheromone to regulate for expression could make some clones less prone to predation than other ones, improving their potential to become serious crop pests. 
In the last decades, several studies analysed the expression of for in insects [23], but it is, at present, unclear if all individuals or only some of them differentially express this gene in the population. These data could be useful to establish a specific relationship between for gene expression and the behavioural plasticity of each population/species. The difficulty of these experiments is related to the presence of multiple unsynchronous individuals in insect populations. In laboratory conditions, as assessed by Nardelli et al. [26], it is possible to collect synchronous $M$. persicae individuals and populations so that it is easier to compare qPCR replicates, avoiding the high range of standard errors observed in previous experiments in other aphid species [13].

Lastly, we compared the for expression in $M$. p. persicae and M. $p$. nicotianae in order to confirm a previous hypothesis suggesting that differences in its expression were related to ecological specialization [14]. Our findings showed very different for expression in the two studied M. p. nicotianae clones (1GK and K1) so that our data did not support this proposal. Even if we agree that the adaptation to new host plants and/or the specialization for some of them may result from the simultaneous contribution of several genes, our data suggest that other mechanisms, such as the upregulation of detoxification-related genes [27] and gene duplications $[28,29]$, could be at the basis of the ecological specialization observed in M. p. nicotianae.

Interestingly, the for gene has been suggested as a possible target for RNA interferencebased field control strategies for the hemipteran Bemisia tabaci [30], further showing that the study of this gene may have an applicative interest for several agricultural pest insects.

\section{Conclusions}

The dispersal of winged females and the presence of exploratory behaviours represent key elements at the basis of the invasiveness of the $M$. persicae populations. As a consequence, the evaluation of the propensity of aphids to disperse in the fields, is essential to plan proper strategies for their control. In view of its involvement in the presence of both alate aphids and explorative behaviours, the screening of the for sequence could be useful as a tool for predicting invasions of cultivated areas by peach potato aphids.

Author Contributions: Both Authors contributed to the present manuscript. Conceptualization: M.M. and G.C.M.; Methodology: M.M.; Formal Analysis: M.M. and G.C.M. Writing, Review and Editing: M.M. and G.C.M. All authors have read and agreed to the published version of the manuscript.

Funding: This research received no external funding.

Acknowledgments: We would like to thank John Margaritopoulos, Brian Fenton and Emanuele Mazzoni for supporting us by sending the M. persicae clones used for our experiments.

Conflicts of Interest: The authors declare no conflict of interest.

\section{References}

1. Osborne, K.; Robichon, A.; Burgess, E.; Butland, S.; Shaw, R.A.; Coulthard, A.; Pereira, H.S.; Greenspan, R.J.; Sokolowski, M.B. Natural behavior polymorphism due to a cGMP-dependant protein kinase of Drosophila. Science 1997, 277, 834-836. [CrossRef] [PubMed]

2. Ben-Shahar, Y.; Robichon, A.; Sokolowski, M.B.; Robinson, G.E. Influence of gene action across different time scales on behaviour. Science 2002, 296, 741-744. [CrossRef] [PubMed]

3. Hammock, E.A. Gene regulation as a modulator of social preference in voles. Adv. Genet. 2007, 59, 107-127.

4. Mansourian, S.; Fandino, R.A.; Riabinina, O. Progress in the use of genetic methods to study insect behavior outside Drosophila. Curr. Opin. Insect Sci. 2019, 36, 45-56. [CrossRef]

5. Lucas, C.; Ben-Shahar, Y. The foraging gene as a modulator of division of labour in social insects. J. Neurogenet. 2021, 35, 168-178. [CrossRef]

6. $\quad$ Lucas, C.; Kornfein, R.; Chakaborty-Chatterjee, M.; Schonfeld, J.; Geva, N.; Sokolowski, M.B.; Avali, A. The locus foraging gene. Arch. Insect Biochem. Physiol. 2011, 74, 249-251. [CrossRef]

7. Fitzpatrick, M.J.; Sokolowski, M.B. In search of food: Exploring the evolutionary link between cGMP-dependent protein kinase (PKG) and behaviour. Integr. Comp. Biol. 2004, 44, 28-36. [CrossRef] [PubMed]

8. Fussnecker, B.; Grozinger, C. Dissecting the role of Kr-h1 brain gene expression in foraging behaviour in honeybees (Apis mellifera). Insect Mol. Biol. 2008, 17, 515-522. [CrossRef] [PubMed] 
9. Garabagi, F.; Wade French, B.; Schaafsma, A.W.; Pauls, K.P. Increased expression of a cGMP-dependent protein kinase in rotation-adapted western corn rootworm (Diabrotica virgifera virgifera L.). Insect Biochem. Mol. Biol. 2008, 38, 697-704. [CrossRef]

10. Tobback, J.; Mommaerts, V.; Vandersmissen, H.P.; Smagghe, G.; Huybrechts, R. Age- and task-dependent foraging gene expression in the bumblebee Bombus terrestris. Arch. Insect Biochem. Physiol. 2011, 76, 30-42. [CrossRef]

11. Sokolowski, M.B. Foraging strategies of Drosophila melanogaster: A chromosomal analysis. Behav. Genet. 1980, 10, $291-302$. [CrossRef] [PubMed]

12. Ben-Shahar, Y. The foraging gene, behavioural plasticity and honeybee division of labor. J. Comp. Physiol. A 2005, 191, 987-994. [CrossRef] [PubMed]

13. Tarès, S.; Arthaud, L.; Amichot, M.; Robichon, A. Environment exploration and colonization behaviour of the pea aphid associated with the expression of the foraging gene. PLoS ONE 2013, 8, e65104. [CrossRef] [PubMed]

14. Tapia, D.H.; Silva, A.X.; Ballesteros, G.I.; Figueroa, C.C.; Niemeyer, H.M.; Ramírez, C.C. Differences in learning and memory of host plant features between specialist and generalist phytophagous insects. Anim. Behav. 2015, 106, 1-10. [CrossRef]

15. Rivi, M.; Monti, V.; Mazzoni, E.; Cassanelli, S.; Panini, M.; Bizzaro, D.; Mandrioli, M.; Manicardi, G.C. Karyotype variations in Italian populations of the peach-potato aphid Myzus persicae (Hemiptera: Aphididae). Bull. Entomol. Res. 2012, 102, 663-671. [CrossRef]

16. Kati, A.N.; Mandrioli, M.; Skouras, P.J.; Malloch, G.L.; Voudouris, C.C.; Venturelli, M.; Manicardi, G.C.; Tsitsipis, J.A.; Fenton, B.; Margaritopoulos, J.T. Recent changes in the distribution of carboxylesterase genes and associated chromosomal rearrangements in Greek populations of the tobacco aphid Myzus persicae nicotianae. Biol. J. Linn. Soc. 2014, 113, 455-470. [CrossRef]

17. Livak, K.J.; Schmittgen, T.D. Analysis of relative gene expression data using real-time quantitative PCR and the $2^{-\Delta \Delta C}{ }_{T}$ method. Methods 2001, 25, 402-408. [CrossRef]

18. Ben-Shahar, Y.; Leung, H.T.; Pak, W.L.; Sokolowski, M.B.; Robinson, G.E. cGMP- dependent changes in phototaxis: A possible role for the foraging gene in honeybee division of labor. J. Exp. Biol. 2003, 206, 2507-2515. [CrossRef]

19. Heylen, K.; Gobin, B.; Billen, J.; Hu, T.T.; Arckens, L. Amfor expression in the honeybee brain: A trigger mechanism for nurse-forager transition. J. Insect Physiol. 2008, 54, 1400-1403. [CrossRef]

20. Ingram, K.K.; Oefner, P.; Gordon, D.M. Task-specific expression of the foraging gene in harvester ants. Mol. Ecol. 2005, 14, 813-818. [CrossRef]

21. Ingram, K.K.; Kleeman, L.; Peteru, S. Differential regulation of the foraging gene associated with task behaviours in harvester ants. BMC Ecol. 2011, 11, e19. [CrossRef] [PubMed]

22. Lucas, C.; Sokolowski, M.B. Molecular basis for changes in behavioural state in ant social behaviours. Proc. Natl. Acad. Sci. USA 2009, 106, 6351-6356. [CrossRef] [PubMed]

23. Anreiter, I.; Sokolowski, M.B. The foraging gene and its behavioural effects: Pleiotropy and plasticity. Annu. Rev. Genet. 2019, 53, 373-392. [CrossRef] [PubMed]

24. L'Etoile, N.D.; Coburn, C.N.; Eastham, J.; Kistler, A.; Gallegos, G. The cyclic GMP-dependent protein kinase EGL-4 regulates olfactory adaptation in C. elegans. Neuron 2002, 36, 1079-1089. [CrossRef]

25. Hatano, E.; Kunert, G.; Weisser, W.W. Aphid wing induction and ecological costs of alarm pheromone emission under field conditions. PLoS ONE 2010, 5, e11188. [CrossRef]

26. Nardelli, A.; Peona, V.; Toschi, A.; Mandrioli, M.; Manicardi, G. Afit: A bioinformatic tool for measuring aphid fitness and invasiveness. Bull. Entomol. Res. 2017, 107, 458-465. [CrossRef]

27. Bass, C.; Zimmer, C.T.; Riveron, J.M.; Wilding, C.S.; Wondji, C.S.; Kaussmann, M.; Field, L.M.; Williamson, M.S.; Nauen, R. The molecular basis of an insect host shift. Proc. Nat. Acad. Sci. USA 2013, 110, 19460-19465. [CrossRef]

28. Mandrioli, M.; Salvatore, D.; Ferrari, A.; Patelli, N.; Manicardi, G.C. Comparative analysis of intra- and inter-specific genomic variability in the peach potato aphid, Myzus persicae. Insects 2019, 10, e368. [CrossRef]

29. Mandrioli, M.; Manicardi, G.C. Evolutionary insights into the aphid genome: Aphid genomics between quality problems and intriguing perspectives. Int. Rev. Cell Mol. Biol. 2020, 354, 215-230.

30. Shelby, E.A.; Moss, J.B.; Andreason, S.A.; Simmons, A.M.; Moore, A.J.; Moore, P.J. Debugging: Strategies and considerations for efficient RNAi-mediated control of the whitefly Bemisia tabaci. Insects 2020, 11, e723. [CrossRef] 